\title{
Penerapan Kurikulum Terintegrasi Dalam Mengembangkan Mutu Belajar Siswa (Studi Kasus di SMA Darul ‘Ulum 1 Unggulan BPPT Jombang)
}

\author{
Nurul Indana \\ Program Studi Pendidikan Agama Islam \\ Sekolah Tinggi Ilmu tarbiyah Al Urwatul Wutsqo Jombang \\ Email : nurulindana91@gmail.com
}

\begin{abstract}
The appearance of schools that integrated some curriculums is aimed to improve learning quality and students learning. One of schools which have implemented the curriculum is SMA Darul 'Ulum 1 BPPT Jombang. This research focused on integrated curriculum implementation, and students learning quality in SMA Darul 'Ulum 1 BPPT Jombang. This study uses qualitative approach, and single case study as design. Data collection technique in this study is interview, observation, and documentation. To analyze the data, the researcher uses descriptive analysis. The researcher uses extension of participation, and perseverance of observation to check the validity. The result of the study shows that: 1 . The implementation of integrated curriculum a). The integrated curriculum model is an integrated educational system between national and the cottage curriculum, an integrated PAI material is combined between PAI of diknas with cottage material, and integration between school and huts activities. b) in planning the curriculum, the school involved head master, teachers, foundation, committee, team of BPPT. after the curriculum was structured, the teachers are asked to make teaching and learning activities planning. in this case, they have to make syllabus, lesson plan, compile learning strategy, etc. c) the curriculum implementation based on the planning has been made in the lesson plan which characterized by integrating between general formal education with religious education in Islamic Boarding Schools. d) the school uses summative and formative evaluation and non-test tests as the evaluation type. 2 . The quality of learning cognitive aspects can be seen from the achievements of students academic field mostly, and student learning outcomes from the test scores, middle, final, and National test which are increasing, the affective aspects are proved by the changes of students attitudes, morals, interests and respect either inside, or outside the class room, both with the teacher and with other students. And the psychomotor aspects are seen from the activities, the results of the skills and competencies achieved both at the district, provincial and national levels.
\end{abstract}

Keywords : Transformational Leadership, Character Building 


\section{A. PENDAHULUAN}

Pendidikan Islam berkembang dengan melalui beberapa masa, yang pertama, masa awal pembinaan pendidikan islam yaitu di masa Rasulullah SAW, kedua, masa pertumbuhan dan perkembangan pendidikan islam terjadi pada masa nabi Muhammad dan khulafāurrasyidin, ketiga, masa kejayaan pendidikan islam terjadi pada masa pemerintahan Bani Umayyah dan Abbasiyah, keempat, masa kemunduran pendidikan islam, di mana kondisi umat islam saat itu cenderung hanya berpikir secara tradisional dan tidak mau berpikir dengan pola rasional ${ }^{1}$. Pendidikan merupakan suatu kebutuhan hidup umat manusia yang mutlak dipenuhi dalam upaya untuk meningkatkan harkat, martabat, dan taraf hidup manusia. Dengan pendidikan manusia akan mengetahui beberapa hal tentang rahasia alam raya beserta manfaatnya untuk dapat melangsungkan dan melestarikan keturunan mereka serta mampu menjawab tantangan perubahan zaman.

Pendidikan mempunyai peran yang sangat penting dalam membangun bangsa dan negara serta bagi individu masing-masing. Karena pendidikan dianggap sebagai kebutuhan pokok manusia untuk dapat melangsungkan hidup dan melestarikan keturunan mereka serta mampu menjawab tantangan perubahan zaman. UndangUndang Sistem Pendidikan Nasional No. 20 tahun 2003 menyatakan bahwa pendidikan adalah usaha sadar dan terencana untuk mewujudkan suasana belajar dan proses pembelajaran agar peserta didik secara aktif mengembangkan potensi dirinya untuk memiliki kekuatan spritual keagamaan, pengendalian diri, kepribadian, kecerdasan, akhlak mulia serta keterampilan yang diperlukan dirinya, masyarakat bangsa dan Negara. ${ }^{2}$

1 Ali Mustofa, Arah Pembaharuan Pendidikan Islam (Analisis Sejarah Perkembangan Pemikiran Modern dalam Islam), Jurnal Pikir Vol 1 No 2 (2015): Studi Pendidikan dan Hukum Islam, (LP3M), STAI Darussalam Krempyang Nganjuk), 89.

2 Tim Penyusun. UU RI no 20 Tabun 2003 Tentang Sisdiknas. (Surabaya: Media Centre. 2005) 3.
"Sejalan dengan itu, pendidikan Islam merupakan proses mengubah tingkah laku individu pada kehidupan pribadi, masyarakat dan alam sekitarnya, dengan cara pengajaran sebagai suatu aktivitas asasi dan profesi diantara profesiprofesi asasi dan masyarakat." 3

"Muhammad SA Ibrahimy (Bangladesh) mengemukakan: Islamic education in true sense of the term, is a system of education which enables a man to lead his life according to the Islamic ideology, so that he may easily mould his life in accorancee with tenetn of Islam"

Pendidikan dalam pandangan yang sebenarnya adalah suatu sistem pendidikan yang memungkinkan seorang dapat mengarahkan kehidupannya sesuai dengan cita-cita Islam, sehingga dengan mudah ia dapat membentuk hidupnya sesuai dengan ajaran Islam. dari dua pengertian tersebut menunjukkan bahwa pendidikan haruslah bisa menciptakan output yang mempunyai kemampuan tentang IMTAQ dan IPTEK.

Banyak faktor yang mempengaruhi pendidikan, salah satu faktor pentingnya adalah kurikulum. Kurikulum sebagai pedoman pelaksanaan pengajaran dan pembelajaran memiliki peran yang penting untuk mensukseskan tujuan pendidikan. Pendidikan yang berkualitas akan terwujud bila kurikulum yang disusun dan dikembangkan juga berkualitas.

Kurikulum yang dirancang dan dikembangkan oleh sekolah/madrasah sudah seharusnya relevan dengan kebutuhan masyarakat. Sebab kurikulum dipersiapkan dan dikembangkan untuk mencapai tujuan pendidikan, yakni mempersiapkan peserta didik agar mereka dapat hidup di masyarakat. Sebagaimana peran sekolah yang berupaya menjadi laboratorium kehidupan sosial masyarakat, sehingga peserta didik yang telah berproses di sekolah tersebut diharapkan telah

3 Bukhori Umar, Imu Pendidikan Islam. (Jakarta: AMZAH, 2011), 7.

${ }^{4}$ Bukhori Umar, Ilmu Pendidikan Islam. (Jakarta: AMZAH, 2011), 27. 
siap untuk terjun dan berbaur dalam kehidupan sosial masyarakat sesungguhnya.

Hasibuan mengemukakan dalam pengembangan kurikulum, komponen isi kurikulum yang berupa materi-materi pelajaran selalu diupayakan disajikan lebih mudah untuk dicerna oleh peserta didik dan lebih memberikan pengetahuan yang komprehensif. Selain itu, relevansi penyajian materi kurikulum harus tetap diutamakan, sehingga materi-materi yang disajikan mampu mendorong peserta didik untuk melahirkan cara berpikir yang lebih dapat memacu kecerdasannya. Sesungguhnya penyajian setiap materi kurikulum dalam bentuk mata pelajaran-mata pelajaran ada kaitannya dengan pembentukan cara berpikir peserta didik. ${ }^{5}$

Adapun yang menjadi permasalahan pokok mengenai kurikulum adalah bagaimana mendesain kurikulum yang benar-benar dapat dijadikan pedoman untuk mencapai tujuan-tujuan pendidikan yang sekaligus menjadi tujuan hidup masyarakat. Hal ini penting diperhatikan karena pendidikan selalu terkait dengan kehidupan, pendidikan tidak hanya untuk pendidikan akan tetapi pendidikan untuk kehidupan. Karena itu, tujuan pendidikan harus dirancang berdasarkan pandangan-pandangan hidup dan sekaligus menjadi tujuan-tujuan hidup masyarakat. Setiap praktik pendidikan diarahkan pada pencapaian tujuan-tujuan tertentu, apakah berkenaan dengan penguasaan pengetahuan, pengembangan pribadi, kemampuan sosial, ataupun kemampuan bekerja.

Ada bermacam-macam bentuk kurikulum dalam dunia pendidikan, diantara kurikulum itu adalah kurikulum terintegrasi (integratet curriculum). Kurikulum terintegrasi adalah suatu bentuk kurikulum yang meniadakan batas-batas antara berbagai mata pelajaran dan menyajikan berbagai bahan pelajaran dalam bentuk unit atau keseluruhan. Kurikulum yang menggunakan pendekatan keterintegrasian ini merupakan suatu kurikulum dengan sistem totalitas yang terdiri dari komponen-komponen yang saling

${ }^{5}$ Malayu Hasibuan, S.P. Manajemen Sumber Daya Manusia. (Jakarta: Bumi Aksara. 2010),55. berhubungan dan berinterakasi baik dari komponen dengan komponen maupun antar komponen dengan keseluruhan, dalam rangka mencapai tujuan yang di tentukan sebelumnya. Pendekatan sistem ini menitik beratkan pada keseluruhan lalu bagian-bagian dan unsur-unsur dan interaksi antara bagian bagian dengan keseluruhan. Konsep keterintegrasian pada hakikatnya menunjuk pada keseluruhan, kesatuan, kebulatan, kelengkapan, kompleksitas yang ditandai oleh interaksi dan interpendensi antara komponen-komponennya.

Pengintegrasian kurikulum ini dimaksudkan dengan tujuan guna menciptakan pemahaman siswa yang menyeluruh. Hal ini dikarenakan Ada kecenderungan selama ini guru mengemas pengalaman belajar siswa terkotakkotak dengan tegas antara satu bidang study dengan bidang studi yang lainnya, pembelajaran yang memisahkan penyajian matamata pelajaran secara tegas hanya akan membuat kesulitan belajar bagi siswa, karena pemisahan seperti itu hanya akan memberikan pengalaman belajar yang bersifat artificial.

"Upaya memperbaiki dan meningkatkan mutu pendidikan seakan tidak pernah berhenti. Banyak agenda reformasi yang telah, sedang dan akan dilakanakan. Beragam progam inovatif ikut serta memeriakan reformasi pendidikan." 6 Reformasi pendidikan tidak hanya dengan merubah kurikulum. Perubahan akan lebih bermakna dan sampai pada tujuan dengan perubahan praktik belajar yang tentunya mengunakan model belajar yang efektif dan efisien. Semuanya dilakukan dalam rangka pembaruan pendidikan.

Pembaruan adalah proses atau cara menghasilkan perubahan dalam penyesuaian situasi dan kondisi. Pendidikan Islam adalah proses mempersiapkan generasi muda (pembentukan individu) untuk menjalankan kehidupan (sebagai khalifah) dan untuk memenuhi tujuan hidup secara efektif dan efisien berdasarkan sumber-sumber Islam berupa alQuran, sunnah, dan ijtihad. Pembaruan

6 Abdul Majid, Perencanaan Pembelajaran, Mengembangkan Standar Kompetensi Guru. (Bandung: Remaja Rosdakarya, 2009), 3. 
pendidikan Islam merupakan tuntutan kebutuhan dunia pendidikan Islam saat ini. Melihat ketertinggalan dan keterbelakangan umat Islam dewasa ini, maka inti dari pembaruan pendidikan Islam adalah berupaya meninggalkan pola pikir lama yang tidak sesuai dengan kemajuan zaman (future oriented) dan berupaya meraih aspekaspek yang menopang untuk menyesuaikan diri dengan kemajuan zaman.

Satu dasawarsa terakhir, dunia pendidikan di Indonesia mengalami perkembangan yang sangat pesat. Hal ini, salah satunya ditandai dengan banyaknya sekolahsekolah baru yang bermunculan. Sebagian dari sekolah-sekolah baru tersebut tidak hanya mengunakan kurikulum nasional, akan tetapi juga menggunakan kurikulum dari luar negeri dan kurikulum pesantren sebagai nilai tambah yang ditawarkan bagi para calon siswa. Yang kemudian lahirlah istilah Sekolah Nasional Plus yang mengintegrasikan beberapa kurikulum.

Kemunculan sekolah yang mengintegrasikan beberapa kurikulum adalah dalam rangkah sebuah upaya untuk meningkatkan mutu belajar dan pembelajaran pada siswa. Pendidikan bermutu adalah pendidikan yang mampu melakukan proses pematangan kualitas peserta didik yang dikembangkan dengan cara membebaskan peserta didik dari ketidaktahuan, ketidakmampuan, ketidakberdayaan, ketidakbenaran, ketidakjujuran, dan dari buruknya akhlak dan keimanan.

"Pendidikan bermutu lahir dari system perencanaan yang baik (good planning system) dengan materi dan system tata kelola yang baik (good governance system) dan disampaikan oleh guru yang baik (good teachers)dengan komponen pendidikan yang bermutu, khususnya guru. Mutu pendidikan menurut Permendiknas nomor 63 tahun 2009 adalah tingkat kecerdasan kehidupan bangsa yang dapat diraih dari penerapan Sistem Pendidikan Nasional." 7

7 Dedy Mulyasana,Pendidikan Bermutu dan Berdaya Saing. (Bandung:Rosda karya, 2011), 120.
Salah satu contoh lembaga pendidikan yang menarik untuk diteliti kemudian ditiru dan dicontoh adalah SMA Darul 'Ulum 1 BPPT Jombang. Sekolah tersebut dalam naungan pondok pesantren, akan tetapi SMA Darul 'Ulum 1 BPPT jombang bisa menerapkan kurikulum adaftif sejak berdirinya, yaitu mengadaptasikan kurikulum Nasional dengan kurikulum pondok Pesantren dengan tujuan untuk mencetak peserta didik yang tidak hanya unggul dalam IPTEK saja, akan tetapi juga memiliki keunggulan IMTAQ dan akhlakul Karimah, selain itu juga mengadaptasi kurikulum luar negri, yaitu kurikulum ICAS yang memiliki tujuan untuk menghasilkan generasi baru yang unggul IMTAQ, akhlakul karimah dan IPTEK dalam sekala nasional maupun internasional. Dari uraian teoritik dan empirik peneliti tertarik untuk meneliti lembaga tersebut dengan mengangkat judul: "Penerapan Kurikulum Terintegrasi Dalam Mengembangkan Mutu Belajar Siswa Di SMA Darul 'Ulum 1 BPPT JOMBANG”.

\section{B. KAJIAN TEORI}

\section{Kurikulum}

\section{a. Pengertian Kurikulum}

"Secara harfiah kurikulum berasal dari bahasa latin, curriculum yang berarti bahwa pengajaran. Ada pula yang mengatakan kata tersebut berasal dari bahasa Prancis courier yang berarti berlari.". . Menurut Saebani " "Kurikulum merupakan seperangkat rencana dan pengaturan pendidikan atau pengajaran dan hasil pendidikan atau pengajaran yang harus dicapai oleh anak didik, kegiatan belajar mengajar, pemberdayaan sumber daya pendidikan dalam pengembangan kurikulum itu sendiri."

"Kata kurikulum selanjutnya menjadi istilah yang digunakan untuk

8 S.Nasution, Pengembangan Kurikulum Pendidikan. (Bandung: Citra Adirya Bakti, 1991), 1.

9 Beni Ahmad Saebani, Ilmu Pendidikan Islam. (Bandung: Pustaka Setia. 2009), 249. 
menunjukkan pada sejumlah mata pelajaran yang harus ditempuh untuk mencapai suatu gelar atau ijazah. Pengertian ini sejalan dengan pendapat Crow and Crow dalam bukunya Abudinata, yang mengatakan bahwa kurikulum adalah rancangan pengajaran yang isinya sejumlah mata pelajaran yang disusun secara sistematis sebagai syarat untuk menyelesaikan suatu program pendidikan tertentu." 10

"Konsep yang berlaku di Indonesia dapat dilihat dari definisi kurikulum yang terdapat dalam Undang-undang Sistem Pendidikan Nasional 2013 pasal 1 ayat 11, yang berbunyi: "kirikulum adalah seperangkat rencana dan pengaturan mengenai isi dan bahan pelajaran serta cara yang digunakan sebagai pedoman penyelenggaraan kegiatan belajar mengajar".11 Dari beberapa pendapat tersebut, dapat disimpulkan bahwa kurikulum pada hakekatnya adalah rancangan mata pelajaran bagi suatu kegiatan jenjang pendidikan tertentu.

\section{b. Ciri-ciri dan bentuk-bentuk Kurikulum}

Menurut Nata ${ }^{12}$ menyebutkan lima ciri-ciri kurikulum pendidikan Islam antara lain:

1) Merupakakan tujuan agama dan akhlak pada berbagai tujuannya, kandungan, metode, alat dan tekniknya bercorak agama.

2) Bersikap seimbang diantara berbagai ilmu yang dikandung dalam kurikulum yang akan digunakan.

3) Bersikap menyelurh dalam menata seluruh mata pelajaran yang diperlukan oleh adak didik.

${ }^{10}$ Abuddin Nata, Filsafat Pendidikan Islam. (Jakarta: Gaya Media Pratama, 2005), 175.

${ }^{11}$ Syaifuddin Sabda, Model Kurikulum Terpadu

IPTEK dan IMTAQ (Desain, Pengembangan \&

Implementasi). (Ciputat: Ciputat Press Group. 2006), 26.

12 Beni Ahmad Saebani, Ilmu Pendidikan Islam.

(Bandung: Pustaka Setia. 2009), 176.
4) Kurikulum yang disusun selalu disesuaikan minat dan bakat anak didik.

Adapun bentuk-bentuk

kurikulum secara umum sebagai berikut:

1) Subject Matter Curiculum (berorientasi pada mata pelajaran).

"Kurikulum ini menampilkan bahan pelajaran secara terpisah-pisah. Tujuannnya adalah penguasaan bahan dari tiap mata pelajaran, sehingga bahannya semakin meluas dan mendalam." $" 13$

Subject matter curriculum merupakan organisasi kurikulum yang tertua dan banyak digunakan di berbagai negara. Subject matter curriculum adalah organisasi materi pendidikan dalam bentuk mata-mata pelajaran yang disajikan dan diberikan kepada peserta didik secara terpisah. Mata-mata pelajaran itu biasanya berupa pengetahuan yang telah disusun secara sistematis dan logis yang diberikan sesuai ndengan jenjang-jenjang tertentu.

Ciri-cirinya adalah mata pelajaran yang diklasifikasikan sesuai dengan bidang keilmuan/pengetahuan ilmiah, memberikan tekanan pada isi dan teknik memberikan pelajaran. Mata pelajaran umumnya bersifat konstan dan tidak banyak perubahan, meskipun perkembangan ilmu pengetahuan mengalami peningkatan. Perencanaan program pengajaran disusun terlebih dahulu untuk mengembangkan subject matter curriculum yang optimal, diperlukan beberapa sarana, baik personal, material, dan fasilitas lainnya.

2) Integrated Curriculum (kurikulum yang terintegrasi)

${ }^{13}$ Soekidjo Notoatmodjo, Pengembangan Sumber Daya Manusia. (Jakarta: Rineka Cipta, 2009) 19. 
Kurikulum ini adalah suatu integrated penuh antar semua mata pelajaran, kurikulum diberikan secara bersama untuk memecahkan suatu masalah. Dalam Integrated Curriculum, pelajaran dipusatkan pada suatu masalah atau topik tertentu, misalnya suatu masalah dimana semua mata pelajaran dirancang dengan mengacu pada topik tertentu." 14

Pola organisasi kurikulum ini memperhatikan warna disiplin ilmu. Bahan ajar diintegrasikan menjadi satu keseluruhan yang disajikan dalam bentuk satuan unit. Dalam satu unit terdapat hubungan antara pelajaran serta berbagai kegiatan siswa. Dengan keterpaduan bahan pelajaran tersebut diharapkan siswa mempunyai pemahaman materi secara utuh. Oleh karena itu, inti yang diajarkan kepada siswa harus memenuhi kebutuhan hidup dilingkungan masyarakat.

3) Kurikulum yang didasarkan pada Tingkat Kemampuan

"Kurikulum yang didasarkan pada tingkat kemampuan (Competensi Based Curriculum), semua kegiatan kurikulum diorganisasi ke arah fungsi atau kemampuan yang dituntut pasaran kerja atau bidang pekerjaan." 15

\section{c. Prinsip dan Asas-asas kurikulum}

"Secara umun ada tiga prinsip dalam pengembangan kurikulum, yaitu 1) prinsip relavansi; 2) prinsip fleksibel; dan 3) prinsip kontinuitas." Sedangkan menurut Langgulung " "menyebutkan prinsip kurikulum pendidikan Islam, yaitu:
1) Prinsip pertautan yang sempurna dengan agama, termasuk ajaran dan nilai-nilainya.

2) Prinsip menyeluruh (universal) pada tujuan-tujuan dan kandungankandungan kurikulum, yakni mencakup tujuan membina akidah, akal, dan jasmani, dan hal lain yang bermanfaat bagi masyarakat dalam perkembangan spiritual.

3) Prinsip keseimbangan yang relatif antara tujuan-tujuan dan kandungan kurikulum.

4) Prinsip keterkaitan antara bakat, minat, kemampuan dan kebutuhan pelajar.

5) Pemeliharaan perbedaan-perbedaan individual diantara pelajar dalam bakat-bakat, kemanpuan-kemanpuan, dan juga memelihara perbedaanperbedaan dan kelainan-kelainan diantara alam sekitar dan masyarakat.

6) Perkembangan dan perubahan." Mengingat sangat pentingnya kurikulum maka dalam pengembangannya diperlikan landasan atau asas yang kuat, melaui pemikiran dan perenungan yang mendalam. Sebuah rumah yang megah akan mudah roboh, jika tidak dibangun dengan pondasi yang kuat dan kokoh. Demikian dengan kurikulum apabila proses pengembangannya secara acakacakan dan tidak memiliki landasan yang kuat maka out put pendidikan yang dihasilakan tidak akan terjamin kualitasnya. Asas-asas yang utama dalam kurikulum yaitu asas filosofis, psikologi, sosiokultural ilmu pengetahuan dan teknologi serta organisatoris. ${ }^{17}$

\footnotetext{
14 Trianto. Model Pembelajaran Terpadu dalam Teori dan Praktek. (Jakarta: Prestasi Pustaka Publisher. 2007), 38.

15 Soekidjo Notoatmodjo, Pengembangan Sumber Daya Manusia. (Jakarta: Rineka Cipta, 2009), 33-34

${ }^{16}$ Beni Ahmad Saebani, Ilmu pendidikan Islam. (Bandung: Pustaka Setia. 2009), 520.
}

\footnotetext{
${ }^{17}$ Muhamad Zaini, Pengembangan Kurikulum: Konsep, Implementasi, Evaluasi dan Inovasi. (Yogyakarta: Teras.
} 2009), 23 


\section{d. Komponen-komponen Kurikulum}

Kurikulum sebagai suatu sistem memiliki komponen-komponen yang saling bekaitan antara yang satu dengan yang lainnya, yakni tujuan, materi, metode, media, evaluasi. Komponen-komponen tersebut baik secara sendiri maupun bersama menjadi dasar utama dalam upaya mengembangkan sistem pembelajaran. ${ }^{18}$ Secara rinci dijelaskan sebagai berikut: komponen tujuan, komponen isi/ materi pelajaran, komponen metode/ strategi dan komponen evaluasi.

\section{e. Evaluasi Kurikulum}

Evaluasi adalah suatu tindakan atau suatu proses untuk menentukan nilai dari sesuatu. Evaluasi dalam pendidikan dapat diartikan sebagai suatu proses dalam usaha untuk mengumpulkan informasi yang dapat digunakan sebagai bahan pertimbangan untuk membuat keputusan akan perlu tidaknya memperbaiki sistem pembelajaran sesuai dengan tujuan yang akan ditetapkan. Tyler seperti yang dikutip Sukmadinata menyatakan bahwa evaluasi adalah proses untuk mengetahui apakah tujuan pendidikan sudah tercapai atau terealisasikan. ${ }^{19}$

\section{Kurikulum Terintegrasi}

a. Pengertian Kurikulum Terintegrasi (Terpadu)

"Integrated curriculum arti sederhananya adalah integrasi kurikulum atau kurikulum terpadu. Menurut S. Nasution, kata integrasi berasal dari kata integer yang mempunyai arti unit. Sehingga integrasi yang dimaksud adalah

${ }^{18}$ Muhamad Zaini, Pengembangan Kurikulum: Konsep, Implementasi, Evaluasi dan Inovasi. (Yogyakarta: Teras. 2009), 79

${ }^{19}$ Muhamad Zaini, Pengembangan Kurikulum: Konsep, Implementasi, Evaluasi dan Inovasi. (Yogyakarta: Teras. 2009), 142-143 perpaduan, koordinasi, harmoni, kebulatan keseluruhan" 20

Forgarty dalam Syaifuddin Sabda mendefinisikan kurikulum terpadu (integrated curriculum) sebagai suatu model kurikulum yang dapat mengintegrasikan skills, themes, concepts, and topics secara inter dan antar disiplin atau penggabungan keduanya. Maurer dalam Syaifuddin Sabda mendefinisikan kurkulum terpadu (interdisciplinary curriculum) sebagai: "the organization and tarnfer of knowledge under a united or interdisciplinary theme". Beane dalam Syaifuddin Sabda mendefinisikannya sebagai model kurikulum yang menawarkan sejumlah kemungkinan tentang kesatuan dan keterkaitan antara kegiatan sehari-hari dengan pengalaman di sekolah atau pengalaman pendidikan. ${ }^{21}$ "Integrasi kurikulum ini bisa dilakukan melalui pengajaran unit atau pelajaran yang terpadu. Menurut Caswell yang dikutip S. Nasution, yang dimaksud pengajaran unit disini adalah $a$ series of related activities engaged in by children in the process of realizing a dominating purpose which is compatible with the aims of education." 22

Menurut Rusman ${ }^{23}$ untuk memadukan semua mata pelajaran ini bisa dilakukan dengan cara pemusatan mata pelajaran pada satu masalah tertentu dengan alternatif pemecahan

\footnotetext{
${ }^{20}$ Nasution. Asas-Asas Kurikulum. (Jakarta: Bumi Aksara. 1995), 195-196

21 Syaifuddin Sabda, Model Kurikulum Terpadu IPTEK dan IMTAQ Desain, Pengembangan \& Implementasi). (Ciputat: Ciputat Press Group. 2006), 2829.

${ }^{22}$ Nasution, Asas-Asas Kurikulum. (Jakarta: Bumi Aksara. 1995), 196

${ }^{23}$ Rusman, Manajemen Kurikulum. (Jakarta: Rajawali Press. 2012), 65.
} 
melalui berbagai disiplin ilmu atau mata pelajaran yang diperlukan sehingga batas-batas antara antara mata pelajaran dapat ditiadakan.

Dengan menerapkan studi masalah dalam mengembangkan kurikulum, maka dengan muda bisa dilakukan pemaduan pelajaran. Misalanya, pelajaran agama islam kelas XII jurusan IPA memasuki bahasan tentang Isra' Mikraj, maka peristiwa itu bisa diterangkan dalam pelajaran fisika tentang kecepatan. Kecepatan Nabi Muhammad ketika isra' mikraj itu sangat tinggi sehingga seakan-akan tidak masuk akal, dalam ilmu fisika terdapat yang namanya kecepatan yang tak terhingga. Kecepatan yang tak terhingga hanya bisa terjadi kalau bendanya itu tidak mempunyai massa jenis. Massa jenis ini bisa diterangkan dalam pelajaran kimia. Atau masalah itu bisa diterangkan dalam mata pelajaran lainnya.

1) Kelebihan Integrated Curriculum

(a) Mempelajari bahan pelajaran melalui pemecahan masalah dengan cara memadukan beberapa mata pelajaran secara menyuluruh dalam menyelesaikan suatu topik atau permasalahan.

(b) Memberikan kesempatan kepada siswa untuk belejar sesuai dengan bakat, minat dan potensi yang dimilikinya secara individu.

(c) Memberikan kesempatan kepada siswa untuk menyelesaikan masalah secara konprehensif dan dapat mengembangkan belajar secara bekerja sama. (d) Dapat membantu meningkatkan hubungan antara sekolah dengan masyarakat.

(e) Dapat menghilangkan batasbatas yang terdapat dalampola kurikulum yang lain.

2) Kekurangan Integrated Curriculum

(a) Kurikulum dibuat oleh guru dan siswa sehingga memerlukan kesiapan dan kemampuan guru secara khusus dalam pengembangan kurikulum seperti ini.

(b) Bahan pelajaran tidak disusun secara logis dan sistematis.

(c) Bahan pelajaran bersifat sederhana.

(d) Memerlukan biaya, waktu dan tenaga yang banyak.

\section{b. Model Kurikulum Terintegrasi}

Ditinjau dari cara memadukan konsep, keterampilan, topik dan unit tematiknya, Fogarty ${ }^{24}$ mengemukakan 10 model yaitu : 1). Fragmented, 2).Connected, 3). Nested, 4). Sequenced, 5). Shared, 6). Webbed, 7). Threaded, 8). Integrated, 9). Immersed dan 10). Networked. Di bawah ini adalah uraian mengenai masing-masing model.

1. Model Fragmented

Model fragmented adalah model pembelajaran tradisional yang memisah-misahkan disiplin ilmu atas beberapa mata pelajaran seperti Matematika, Sains, Ilmu Sosial, Bahasa dan Seni. Model ini mengajarkan disiplin-disiplin ilmu tersebut secara terpisah dan tanpa ada upaya untuk menghubungkan atau mengintegrasikannya. Model ini mengutamakan kemurnian disiplin ilmu tertentu. Model ini lebih cocok untuk tingkat SMA dan Universitas.

2. Model Connected (Keterhubungan)

${ }^{24}$ Robin Fogarty, How to Integrate the Curricula. (USA: CorwinPress, 1991) 
Model Connected berusaha menghubungkan satu konsep dengan konep lain, topik satu dengan topik lain, satu keterampilan dengan keterampilan lain, ide yang satu dengan ide lain tetapi masih dalam lingkup satu bidang studi misalnya IPA atau IPS. Dengan model connected siswa lebih mudah menemukan keterkaitan karena masih dalam lingkup satu bidang studi, tetapi kurang menampakkan keterkaitan interdisiplin.

\section{Model Nested}

Model Nested merupakan model yang memadukan berbagai bentuk keterampilan yaitu keterampilan social (social skill), keterampilan berpikir (thinking skill) dan keterampilan isi (contentspecific skill) ketika membahas suatu topik. Misalnya ketika siswa mempelajari sistem peredarah darah, targetnya adalah memahami konsep "sistem". Tetapi guru juga mengembangkan keterampilan berpikir siswa dengan cara mengeksplor siswa mengenai faktorfaktor yang menyebabkan dan berpengaruh terhadap gangguan sistem peredaran darah. Keterampilan social juga dikembangkan dengan cara siswa belajar secara berkelompok. Dengan begitu keterampilan-keterampilan tadi "nested" bersama-sama sebagai pengalaman belajar siswa.

4. Model Sequenced

Pada model Sequenced topiktopik atau unit-unit antar mata pelajaran diatur dan diurutkan secara tepat satu sama lain. Materi dari dua mata pelajaran yang berhubungan dapat diurutkan untuk diajarkan secara paralel.Topik-topik itu dapat dipadukan pembelajarannya pada alokasi jam yang sama. Pembelajaran terpadu model sequenced ini ditempuh dalam upaya mengutuhkan dan menyatukan materi-materi yang bercirikan sama dan terkait agar lebih utuh dan menyeluruh.

\section{Model Shared}

Model shared ini merupakan bentuk pemaduan pembelajaran akibat adanya "overlapping" konsep atau ide pada dua mata pelajaran, sehingga menjadi konsep yang utuh terhadap konsep-konsep yang berserakan tersebut sehingga menuntun siswa untuk membuka wawasan dan cara berpikir yang luas dan mendalam melalui pemahaman terhadap konsep lintas disiplin ilmu.

6. Model Webbed (Jaring Laba-laba)

Model webbed ini mewakili pendekatan tematik untuk memadukan materi subjek. Model ini dimulai dengan menentukan tema yang kemudian dikembangkan sub temanya dngan memperhatikan kaitannya dengan bidang studi lain. Biasanya tema yang dipilih harus tema yang "fertil" yaitu tema yang memiliki kemungkinan keterkaiatan yang kaya dengan unsur atau konep lain. Tema yang fertil biasanya berupa pola atau siklus. Tema yang familier membuat motivasi belajar siswa meningkat dan memberi siswa pengalaman berpikir serta bekerja inter disiplin. Akan tetapi sulit untuk menentukan tema yang fertile.

7. Model Threaded ( Pembelajaran Terpadu Bergalur)

Model Threaded merupakan model pemaduan kurikulum berfokus pada metakurikulum. Pembelajaran dengan model ini ditempuh dengan cara mengembangkan gagasan pokok yang merupakan benang merah (galur) yang berasal dari konsep yang terdapat dalam berbagai disiplin ilmu. 
8. Model Integrated (Keterpaduan)

Model Integrated dimulai dengan mengidentifikasi konsep, keterampilan, sikap yang overlap pada beberapa bidang studi. Tema hanya berfungsi sebagai konteks pembelajaran. Kelebihan model ini adalah hubungkan antar bidang studi jelas terlihat melalui kegiatan pembelajaran. Akan tetapi model ini menuntut wawasan yang luas dari guru dan karena terfokus pada kegiatan pembelajaran, terkadang mengabaikan target penguasaan konsep.

9. Model Immersed

Model Immersed dirancang untuk membantu siswa dalam menyaring dan memadukan berbagai pengalaman dan pengetahuan dihubungakan dengan medan pemakaiannya. Dalam hal ini tukar pengalaman sangat diperlukan dalam kegiatan dan disiplin dengan mengaitkan gagasan-gagasan melalui minatnya. Pada model ini keterpaduan terjadi secara internal dan intrinik yang dilakukan oleh siswa dengan sedikit atau tanpa intervensi dari luar. Siswa dalam pembelajaran harus memiliki kemampuan sebagai seorang ahli, sehingga dalam melihat sesuatu dia pandang pada satu kaca mata disiplin yang dimilikinya. Model ini hanya dapat diterapkan pada jenjang pendidikan menengah dan tinggi.

10. Model Networked

Model networked merupakan model pemaduan pembelajaran yang mengendalikan kemungkinan pengubahan konsepsi, bentuk pemecahan masalah, maupun tuntutan bentuk keterampilan baru setelah siswa mengadakan studi lapangan dalam situasi, kondisi maupun konteks berbeda-beda. Belajar disikapi sebagai proses yang berlangsung secara terus menerus karena adanya hubungan timbal balik antara pemahaman dan kenyataan yang dihadapi siswa

$$
\text { Sedangkan menurut Robin }
$$

Fogarty dalam Trianto, model kurikulum terintegrasi dikelompokkan menjadi 3 (tiga) klasifikasi pengintegrasian kurikulum, sebagai berikut: pengintegrasian di dalam satu disiplin ilmu, pengintegrasian beberapa disiplin ilmu dan pengintegrasian di dalam satu dan beberapa disiplin ilmu

Tabel: Klasifikasi Pengintegrasian Kurikulum $^{25}$ yang
diadopsi dari Fogarty

1. Pengintegrasian kurikulum di dalam satu disiplin ilmu (interdisiplin ilmu): The Cellular model (model tergambarkan), the connected model (model terhubung), the nested model (model bersarang)

2. Pengintegrasian kurikulum beberapa disiplin ilmu (antar disiplin ilmu): The squenced model (model terurut), the shared model (model terbagi), the webbed model (model terjaring), the threaded model (model tertali), the integrated model (model terpadu)

3. Pengintegrasian kurikulum di dalam dan beberapa disiplin ilmu (inter dan antar disiplin ilmu): The immersed model (model terbenam), the networked model (model jaringan)

Mengutip pendapat Maurer, Syaifuddin Sabda mengemukakaan enam unsur yang harus ada dalam sebuah desain kurikulum terpadu, yaitu: a) tujuan umum (common objectives), b) tema umum

25 Trianto. Model Pembelajaran Terpadu dalam Teori dan Praktek. (Jakarta: Prestasi Pustaka Publisher, 2007), 42. 
(common theme), c) kerangka waktu (common ime frame), d) pola sequen materi (diverse sequencing pattern), e) strategi aplikasi pembelajaran (applied learning strategies), dan f) bentuk pengukuran (varied assessment). ${ }^{26}$

(1) Tujuan Umum

Dalam konteks teori dan praktik pengembangan kurikulum istilah tujuan sering menggunakan beberapa istilah yang menunjukkan makna dan penggunaaan yang berbeda, yakni "objectives, aims, dan goals". Mengutip pendapat Zais, istilah "objectives" berarti "as the most immediate specific outcomes of classroom instruction". Dalam hal ini tujuan memiliki pengertian tujuan atau bentuk keluaran langsung dan bersifat spesifik dari sebuah dari kegiatan dikelas.oleh karena itu menurutnya "in general, they refer to the everyday business of the operative curriculum", yakni secara umum tujuan dalam trem objective merujuk kepada kegiatan opersional kurikulum seharihari.

Jika istilah-istilah yang dipakai di atas dikaitkan dengan istilah "aims", "goals", dan "objectives", maka istilah tujuan pendidikan nasional dan tujuan institusional dapat dikategorikan sebagai "aims". Sedangkan tujuan kurikuler sebagai "goals" dan tujuan instruksional sebagai "objectives".

(2) Tema Umum

Tema umum (Common Theme) sering juga disebut sebagai "tema sentral", yakni sesuatu yang dijadikan sebagai pengikat pembahasan bagi semua bidang yang ingin dipadukan.sebagai tema umum atau sentral, maka ia adalah sesuatu yang selanjutnya dapat

26 Syaifuddin Sabda, Model Kurikulum Terpadu IPTEK dan IMTAQ (Desain, Pengembangan \& Implementasi). (Ciputat: Ciputat Press Group. 2006), 6162. dijabarkan oleh semua bidang studi yang ingin dipadukan. ${ }^{27}$

(3) Kerangka Waktu Umum

Penentuan kerangka waktu umum sangat penting dalam sebuah kurikulum terpadu. Penetuan kerangka waktu ini berkaitan dengan upaya mengorganisir kegiatan dimana materi-materi pada masing- masing mata pelajaran terkait disajikan dalam waktu yang telah ditentukan.

(4) Ragam Sekuen Materi

Sekuen adalah merupakan organisasi materi dalam bentuk pengaturan urutan materi-materi yang terkait dalam sebuah kurikulum terpadu.

(5) Strategi Aplikasi Kurikulum

Dalam pendidikan, khususnya dalam aplikasi kurikulum perlu diatur dalam pemilihan strategi. Strategi aplikasi kurikulum meliputi: pengaturan guru, pengaturan siswa, struktur peristiwa belajar mengajar, dan pola pengolahan pesan.

\section{c. Perencanaan Kurikulum Terintegrasi}

Perencanaan bertujuan untuk mencapai seperangkat operasi yang konsisten dan terkoordinasi guna memperoleh hasil-hasil yang diinginkan. Secara mendasar, perencanaan adalah suatu proses intelektual yang melibatkan pembuatan keputusan. Proses ini menuntut prediposisi mental untuk berpikir sebelum bertindak, berbuat berdasarkan kenyataan bukan perkiraan, dan berbuat sesuatu secara teratur. ${ }^{28}$ Hal ini, menekankan bahwa perencanaan dalam pengembangan kurikulum terintegrasi merupakan suatu keharusan yang tidak terelakkan. Begitu juga harus mampu mengintegrasi perencanaan dengan tujuan pendidikan di masing-masing skala, apakah skala

${ }^{27}$ Syaifuddin Sabda, Model Kurikulum Terpadu IPTEK dan IMTAQ (Desain, Pengembangan \& Implementasi). (Ciputat: Ciputat Press Group. 2006), 69.

${ }^{28}$ Oemar Hamalik, Manajemen Pengembangan Kurikulum. (Bandung: UPI dan Remaja Rosdakarya, 2008.), 134 
nasional, institusional, kurikuler dan intruksional.

Untuk menyusun perencanan kurikulum terintegrasi, maka harus memperhatikan bentuknya sebagai berikut: Pertama, unit merupakan satu kesatuan dari seluruh bahan pelajaran. Faktor yang menyatukan adalah masalah-masalah yang akan diselidiki dan dipecahkan oleh peserta didik. Segala aktivitas peserta didik harus berkaitan dengan pokok masalah tersebut. Seluruh bahan pelajaran dipergunakan untuk memecahkan masalah yang dihadapi.

Kedua, unit didasarkan pada kebutuhan peserta didik baik yang bersifat pribadi maupun sosial, baik yang menyangkut jasmani dan rohani. Kebutuhan peserta didik biasanya ditentukan oleh latar belakang masyarakatnya. Dengan sistem unit ini, akan meningkatkan perkembangan sosial peserta didik dengan banyak memberikankesempatanbekerjasama dalam kelompok.

Ketiga, dalam unit peserta didik dihadapkan pada berbagai situasi yang mengandung permasalahan yang berhubungan dengan kehidupan sehari-hari dan dikaitkan dengan pelajaran di sekolah sesuai dengan tingkat kemampuan peserta didik.

Keempat, unit mempergunakan dorongan-dorongan sewajarnya pada diri peserta didik dengan melandaskan diri pada teori-teori belajar. Peserta didik diberi kesempatan melakukan berbagai kegiatan sesuai dengan minatnya. Dalam merancang unit peserta didik juga harus diikutsertakan untuk menentukan pokok-pokok masalahnya. Kelima, pelaksanaan unit sering memerlukan waktu yang relatif lebih lama daripada pelajaran biasa di kelas. ${ }^{29}$

${ }^{29}$ Burhan Nurgiyantoro, Penilaian Pembelajaran Bahasa Berbasis Kompetensi. (Yogyakarta: Badan Percetakan Fakultas Ekonomi Universitas Negeri Yogyakarta. 2013), 119.

\section{d. Pelaksanaan Kurikulum Terintegrasi}

Pelaksanaan

kurikulum

direalisasikan dalam proses belajar mengajar sesuai dengan prinsip-prinsip dan tuntutan kurikulum yang telah dikembangkan bagi suatu jenjang pendidikan atau sekolah/madrasah tertentu.

Kegiatan proses belajar mengajar erat kaitannya dengan tugas-tugas seorang guru, kegiatan-kegiatan tersebut antara lain: (a) menyusun rencana pelaksanaan program/unit, (b) menyusun jadwal pelaksanaan kegiatan dan jadwal pelajaran, (c) pengisian daftar penilaian kemajuan belajar dan perkembangan peserta didik, dan (d) pengisian buku laporan pribadi peserta didik.

Dalam pendekatan pelaksanaan kurikulum terintegrasi, peserta didik adalah pembuat keputusan dan para pemecah masalah. Proses dipandang sebagai sentral untuk menjelaskan tingkah laku. Peserta didik itu berbeda satu sama lain, sedangkan masalah merupakan kunci dimana proses dimulai, karena itu pula cara penyelesaian masalah pun berbeda satu sama lain, tidak ada dua cara yang sama. Para peserta didik bukan saja dikembangkan sebagai suatu kepribadian yang bulat, akan tetapi juga dipersiapkan sebagai pribadi yang mampu berperan di masyarakat. Selain dari itu, pendekatan ini memungkinkan kerjasama antara sekolah dan masyarakat. ${ }^{30}$

Pelaksanaan kurikulum ini guru dituntut untuk memiliki kemampuan mengimplementasikan berbagai strategi belajar mengajar yang sesuai dengan karakteristik kurikulum tersebut. Pembelajaran yang mungkin banyak digunakan seperti pemecahan masalah, metode proyek, pengajaran unit, inquiry,

${ }^{30}$ Oemar Hamalik,. Manajemen Pengembangan Kurikulum. (Bandung: UPI dan Remaja Rosdakarya, 2008), 60-62. 
discovery, dan pendekatan tematik yang dilakukan dalam pembelajaran kelompok maupun secara perorangan. Pembelajaran tematik juga merupakan salah satu model dalam pembelajaran terpadu (integrated instruction) yang merupakan suatu sistem pembelajaran yang memungkinkan peserta didik, baik secara individual maupun kelompok, aktif menggali dan menemukan konsep serta prinsip-prinsip keilmuan secara holistik, bermakna dan autentik.

Pendekatan pembelajaran terpadu lebih menekankan pada penerapan konsep belajar sambil melakukan sesuatu (learning by doing). Peserta didik akan memahami konsep-konsep yang mereka pelajari melalui pengalaman langsung dan menghubungkannya dengan konsep lain yang telah dipahaminya. ${ }^{31}$ Kurikulum terintegrasi terwujud pada unit-unit pembelajaran, yang masing-masing unit didukung oleh sejumlah mata pelajaran atau bidang studi. Tiap unit merupakan suatu masalah yang luas dan perlu dipecahkan, dan pemecahannya membutuhkan bahan dari setiap bidang studi. Itu sebabnya, urutan bahan, ruang lingkup dan penempatan bahan untuk setiap unit harus dirancang berdasarkan kebutuhan unit dan sistem instruksional yang dilaksanakan. ${ }^{32}$

Secara lebih rinci menurut Lias Hasibuan, penyajian kurikulum terintegrasi dapat dilakukan dalam bentuk:

1) "Unit curriculum", yaitu kurikulum unit dimana pada tingkat tertentu mengintegrasikan sejumlah mata pelajaran dan difungsikan menjadi suatu komponen untuk mengkaji suatu topik yang sedang dipelajari, pembelajarannya dengan pendekatan multi disipliner.

${ }^{31}$ Rusman, Manajemen Kurikulum. (Jakarta: RajaGrafindo Persada, 2009),254

${ }^{32}$ Hamalik, Oemar. Manajemen Pengembangan Kurikulum. (Bandung: UPI dan Remaja Rosdakarya, 2008), 129.
2) "Project curriculum", yaitu kurikulum dimana materi tertentu yang relevan dari mata pelajaran dipadukan untuk menyelesaikan suatu proyek dalam proses kegiatan belajar-mengajar atau untuk memecahkan suatu masalah. ${ }^{33}$

Sedangkan menurut Nana Syaodih ${ }^{34}$ pengembangan kurikulum terintegrasi prosesnya, sebagai berikut:

1) Menentukan tema-tema (topik) yang membentuk satu kesatuan (unifying theme), yang dapat terdiri atas ide atau konsep besar yang dapat mencakup semua ilmu atau suatu proses kerja ilmu, fenomena alam, atau masalah sosial yang membutuhkan pemecahan secara ilmiah.

2) Menyatukan kegiatan belajar dari beberapa disiplin ilmu. Kegiatan belajar melibatkan isi dan proses dari satu atau beberapa ilmu sosial atau perilaku yang mempunyai hubungan dengan tema yang dipilih/dikerjakan.

3) Menyatukan beberapa cara atau metode belajar. Kegiatan belajar ditekankan pada pengalaman konkret yang bertolak dari minat dan kebutuhan murid serta disesuaikan dengan keadaan setempat.

4) Proses pemilihan topik yang dijadikan isi kurikulum terintegrasi dilakukan langkah-langkah sebagai berikut: Mengindentifikasi topik-topik yang dijadikan bahan untuk dipelajari peserta didik agar tercapai tujuan yang dirumuskan.

\section{e. Evaluasi Kurikulum Terintegrasi}

Evaluasi pengembangan kurikulum dapat dipandang sebagai proses pembuatan keputusan-keputusan tentang kurikulum di dalam sekolah atau proses pengajaran yang dibatasi oleh minat-minat pihak luar, seperti

\footnotetext{
${ }^{33}$ Lias Hasibuan, Manajemen Sumber Daya Manusia, (Jakarta; Bumi Aksara, 2010), 58

${ }^{34}$ Nana Syaodih, Prinsip dan Landasan Pengembangan Kurikulum (Jakarta : P2LPTK, 2005),97.
} 
orang tua, karyawan, masyarakat lokal atau masyarakat luas. ${ }^{35}$

Peranan evaluasi kurikulum bagi pimpinan, berkenaan dengan hal yaitu: evaluasi sebagai moral judgement, evaluasi dan penentuan keputusan, serta evaluasi dan konsensus nilai. ${ }^{36}$ Bagi guru, penyelenggaraan evaluasi hasil penerapan pengembangan kurikulum dalam satu semester, yaitu: evaluasi formatif dan evaluasi sumatif. Kedua jenis evaluasi ini dilaksanakan oleh guru dengan tujuan untuk mengetahui keberhasilan proses penerapan kurikulum di kelas.

a. Evaluasi Formatif

Evaluasi formatif adalah evaluasi atau penilaian yang dilakukan setelah satu pokok bahasan selesai dipelajari oleh peserta didik. Evaluasi formatif terutama dimaksudkan untuk memberikan umpan balik kepada guru mengenai keberhasilan proses belajar mengajarnya. Evaluasi formatif ini dapat dilaksanakan dengan tes tertulis maupun lisan.

b. Evaluasi Sumatif

Evaluasi sumatif adalah tes yang diselenggarakan oleh guru setelah menempuh satu jangka waktu tertentu. Dalam pelaksanaan tes sumatif ini sering disebut dengan ulanngan atau ujian semester, atau ulangan umum nasional dan biasanya diselenggarakan secara serempak untuk seluruh sekolah. Dalam evaluasi sumatif, evaluasi berfungsi untuk menetapkan keseluruhan penilaian program.

Evaluasi kurikulum memegang peranan penting baik dalam penentuan kebijaksanaan pendidikan pada umumnya, maupun pada pengambilan keputusan

35 Hamalik, Oemar. Manajemen Pengembangan Kurikulum. (Bandung: UPI dan Remaja Rosdakarya, 2008), 141.

${ }^{36}$ Nana Syaodih, Prinsip dan Landasan Pengembangan Kurikulum (Jakarta : P2LPTK, 2005),180 dalam pengembangan kurikulum. Hasilhasil evaluasi dapat digunakan oleh para pemegang kebijaksanaan pendidikan dan para pengembang kurikulum dalam memilih dan menetapkan kebijaksanaan pengembangan sistem pendidikan dan pengembangan model kurikulum yang digunakan. $^{37}$

Dalam evaluasi kurikulum terintegrasi, penilaian pencapaian kompetensi dasar peserta didik dilakukan berdasarkan indikator. Penilaian dilakukan dengan menggunakan tes dan non tes dalam bentuk tertulis maupun lisan, pengamatan kinerja, pengukuran sikap, penilaian hasil karya berupa tugas, proyek dan/atau produk, penggunaan portofolio dan penilaian diri.

\section{Pembahasan Mutu Belajar}

\section{a. Pengertian Mutu Belajar}

Mutu adalah sebuah proses terstruktur untuk memperbaiki keluaran yang dihasilkan. Fokous mutu didasari upaya positif yang dilakukan individu. Dalam sekolah mutu, standar mutu ditetapkan untuk setiap rangkaian kerja di dalam keseluruhan proses kerja. Bila pekerja mencapai standar mutu untuk masing-masing rangkaian kerja, hasil akhirnya adalah sebuah produk bermutu.

Menurut $\mathrm{Juran}^{38}$, mutu sebagai "tempat untuk pakai" dan menegaskan bahwa dasar misi mutu sebuah sekolah adalah "mengembangkan program dan layanan yang memenuhi kebutuhan pengguna seperti siswa dan masyarakat". Sedangkan menurut ISO 2000 , mutu adalah totalitas karakteristik suatu produk (barang dan jasa) yang menunjang kemampuannya untuk memuaskan kebutuhan yang dispesifikan atau ditetapkan.

${ }^{37}$ Nana Syaodih, Prinsip dan Landasan Pengembangan Kurikulum (Jakarta : P2LPTK, 2005), 172

38 Jerry H Makawimbang, Supervisi dan Peningkatan Mutu Pendidikan. (Bandung: Alfabeta, 2011), 42. 
Saat membicarakan perbaikan mutu pendidikan, seringkali yang dibicarakan adalah perbaikan peringkat kenaikan kelas atau nilai rapor. Dalam sekolah yang bertipe seperti itu, tanggung jawab perbaikan mutu pendidikan lebih banyak ada pada guru. Secara umum para guru terfokus hanya pada aspek pendidikan seorang siswa: membantu siswa belajar dan mendapatkan pengetahuan. Bila mutu dimulai sebagai proyek terislasi di sekolah atau ruang kelas, dan hal tersebut hamper mempengaruhi keseluruhan mutu pendidikan.

Misalnya, guru secara aktif telah mutu dikelasnya sejak tujuh tahun silam. Dia bersifat instrumental dalam membentu guru lain mengembangkan pemahaman mutu. Namun, mutu di sekolah bergantung pada mutu guru di kelas. Banyak rekan-rekan gurunya yang enggan menerima tantangan mutu. Tipe impementasi mutu seperti ini disebut mutu dengan $m$-kecil.

Sebaliknya mutu sekolah dengan $M$-besar membuat setiap orang bertanggung jawab pada mutu. Orang diperlengkapi dengan alat yang dibutuhnkannya untuk mengubah cara kerjanya untuk memperbaiki mutu keluaran mereka. Orang bertanggung jawab mengurangi pemborosan dan inefisiensi. Sebagai hasil dari upaya itu, mereka menciptakan pembelajaran dan linkungan kerja yang baik. ${ }^{39}$

Pendidikan bermutu adalah pendidikan yang mampu melakukan proses pematangan kualitas peserta didik yang dikembangkan dengan cara membebaskan peserta didik dar ketidaktahuan, ketidakmampuan, ketidakberdayaan, ketidakbenaran, ketidakjujuran, dan dari buruknya akhlak dan keimanan.
Pendidikan bermutu lahir dari system perencanaan yang baik (good planning system) dengan materi dan system tata kelola yang baik (good governance system) dan disampaikan oleh guru yang baik (good teachers)dengan komponen pendidikan yang bermutu, khususnya guru.

Mutu pendidikan menurut Permendiknas nomor 63 tahun 2009 adalah tingkat kecerdasan kehidupan bangsa yang dapat diraih dari penerapan Sistem Pendidikan Nasional, sedangkan belajar adalah suatu proses perubahan yang relatif permanen pada pengetahuan, kemampuan, keterampilan, dan tingkah laku, yang terjadi sebagai hasil dari usaha yang disengaja dan pengalaman yang terkontrol dan tidak terkontrol. Definisi tersebut menunjukkan bahwa belajar adalah suatu proses perubahan yang relatif permanen pada tingkah laku yang terjadi sebagai hasil dari pengalaman yang terkontrol dan tidak terkontrol, dan belajar merupakan proses pemerolehan keterampilan, pengetahuan, kemampuan, dan tingkah laku yang mempengaruhi deskripsi dan diagnosa terhadap peristiwa dan manusia. ${ }^{40}$

Uraian di atas menunjukkan bahwa mutu pembelajaran dianggap bermutu bila berhasil mengubah sikap, perilaku dan keterampilan peserta didik dikaitkan dengan tujuan pendidikannya. Mutu pendidikan sebagai sistem selanjutnya bergantung pada mutu komponen yang membentuk sistem, serta proses pembelajaran yang berlangsung hingga membuahkan hasil.

Berdasarkan uraian di atas menunjukkan bahwa mutu adalah sesuatu kesempatan untuk menempatkan pada posisi kompetitif. Mutu pada dasarnya merupakan penyesuaian manfaat atau kegunaan. Artinya
39 Jerome S Arcaro, Pendidikan Berbasis Mutu. (Yogyakarta: Pustaka Pelajar. 2005), 75-77.
${ }^{40}$ Dedy Mulyasana, Pendidik Bermutu dan Berdaya Saing (Bandung: Remaja Rosdakarya, .2011), 110 
harapan sesuai dengan kepuasan pemakai.

Mutu pembelajaran ditentukan oleh tiga variabel, yakni budaya sekolah, proses belajar mengajar, dan realitas sekolah. Budaya sekolah merupakan nilai-nilai, kebiasaankebiasaan, upacara-upacara, sloganslogan, dan berbagai perilaku yang telah lama terbentuk di sekolah dan diteruskan dari satu angkatan ke angkatan berikutnya, baik secara sadar maupun tidak. Budaya ini diyakini mempengaruhi perilaku seluruh komponen sekolah, yaitu guru, kepala sekolah, staf administrasi, siswa, dan juga orang tua siswa. Budaya yang kondusif bagi peningkatan mutu akan mendorong perilaku warga kearah peningkatan mutu sekolah, sebaliknya budaya yang tidak kondusif akan menghambat upaya menuju peningkatan mutu sekolah.

Berkaitan dengan komponenkomponen yang membentuk sistem pendidikan, lebih rinci Syaodih ${ }^{41}$ mengemukakan bahwa komponen input diklasifikasikan menjadi tiga, yaitu:

(1) Raw input, yaitu siswa yang meliputi intelek, fisik-kesehatan, sosial-afektif dan peer group.

(2) Instrumental input, meliputi kebijakan pendidikan, program pendidikan (kurikulum), personil (Kepala sekolah, guru, staf TU), sarana, fasilitas, media, dan biaya.

(3) Environmental input, meliputi lingkungan sekolah, lingkungan keluarga, masyarakat, dan lembaga sosial, unit kerja.
Komponen proses menurut Syaodih $^{42}$, meliputi pengajaran, pelatihan, pembimbingan, evaluasi, ekstrakulikuler, dan pengelolaan. Selanjutnya output meliputi pengetahuan, kepribadian dan performansi. Berdasarkan pendapat di atas, dapat diketahui bahwa proses pembelajaran merupakan salah satu komponen sistem

pendidikan yang dapat menentukan keberhasilan pembelajaran dan mutu pendidikan. Oleh karena itu untuk memperoleh mutu pendidikan yang baik, diperlukan proses pembelajaran yang berkualitas pula.

Dalam rangka mewujudkan mutu pembelajaran yang berkualitas, pemerintahmengeluarkan Peraturan Pemerintah No. 19 tahun 2005 tentang Standar Nasional Pendidikan (SNP) sebagai penjabaran lebih lanjut dari Undang-undang Sistem Pendidikan Nasional, yang di dalamnya memuat tentang standar proses. Dalam Bab I Ketentuan Umum SNP, yang dimaksud dengan standar proses adalah standarnasional pendidikan yang berkaitan dengan pelaksanaan pembelajaran pada satuan pendidikan untuk mencapai standar kompetensi lulusan. Bab IV Pasal 19 Ayat 1 SNP lebih jelas menerangkan bahwa proses pembelajaran pada satuan pendidikan diselenggarakan secara interaktif, inspiratif, menyenangkan, menantang, memotivasipeserta didik untuk berpartisipasi aktif, serta memberikan ruang yang cukup bagiprakarsa, kreativitas, dan kemampuan sesuai bakat, minat dan perkembangan fisik dan psikologis peserta didik.

Mutu pembelajaran merupakan hal pokok yang harus dibenahi dalam

\footnotetext{
${ }^{41}$ Nana Syaodih, Prinsip dan Landasan Pengembangan Kurikulum (Jakarta : P2LPTK, 2005), 70
}

${ }^{42}$ Nana Syaodih, Prinsip dan Landasan Pengembangan Kurikulum (Jakarta : P2LPTK, 2005), 6 
rangka peningkatan mutu pendidikan. Dalam hal ini guru menjadi titik fokusnya. Berkenaan dengan ini Suhardan ${ }^{43}$ mengemukakan pembelajaran pada dasarnya merupakan kegiatan akademik yang berupa interaksi komunikasi anatara pendidik dan peserta didik proses ini merupakan sebuah tindakan professional yang bertumpu pada kaidah-kaidah ilmiah. Aktivitas ini merupakan kegiatan guru dalam mengaktifkan proses belajar peserta didik dengan menggunakan berbagai metode belajar. Pembelajaran adalah suatu kombinasi yang tersusun meliputi unsur-unsur manusiawi, material, fasilitas, perlengkapan, dan prosedur yang saling mempengaruhi mencapai tujuan pembelajaran. ${ }^{44}$

Berkaitan dengan pembelajaran yang bermutu, Mulyono menyebutkan bahwa konsep mutu pembelajaran mengandung lima rujukan, yaitu: 1 . Kesesuaian, 2. Pembelajaran, 3. Efektivitas, 4. Efisiensi, 5. Produktivitas. Pembelajaran yang bermutu akan bermuara pada kemampuan guru dalam proses pembelajaran. Secara sederhana kemampuan yang harus dimiliki oleh guru yaitu kemampuan merencanakan pembelajaran, proses pembelajaran, serta evaluasi pembelajaran. ${ }^{45}$

Kegiatan belajar mengajar dilaksanakan dalam suasana tertentu dengan dukungan sarana dan prasarana pembelajaran tertentu tertentu pula. Oleh karena itu, keberhasilan mutu pembelajaran sangat tergantung pada: guru, siswa, sarana pembelajaran, lingkungan kelas, dan budaya kelas.

${ }^{43}$ Dadang Suhardan, Supervisi Profesional Layanan dalam Meningkatkan Mutu Pengajaran di Era Otonomi Daerah). (Bandung: Alfabeta, 2010), 67.

44 Oemar Hamalik, Manajemen Pengembangan Kurikulum. (Bandung: UPI dan Remaja Rosdakarya, 2008.), 57.

${ }^{45}$ Mulyono Abdurrahman, Pendidikan Bagi Anak Berkesulitan Belajar, (Jakarta: PT Rineka Cipta, 2009.), 29
Semua indikator tersebut harus saling mendukung dalam sebuah system kegiatan pembelajaran yang bermutu.

Dalam Undang-Undang N0.20 Tahun 2003, tentang Sistem Pendidikan Nasional, istilah belajar tidak ditemukan. Istilah yang digunakan adalah pembelajaran. Pembelajaran didefinisikan sebagai proses interaksi peserta didikdengan pendidik dan sumber belajar pada suatu lingkungan belajar.Dalam proses pembelajaran dikenal beberapa istilah yang memiliki kemiripan makna, sehingga seringkali orang merasa bingung untuk membedakannya. Istilahistilah tersebut adalah: (1) pendekatan pembelajaran, (2) strategi pembelajaran, (3) metode pembelajaran; (4) teknik pembelajaran; (5) taktik pembelajaran; dan (6) model pembelajaran.

Dalam pembelajaran yang bermutu terlibat berbagai input pembelajaran seperti; siswa (kognitif, afektif, atau psikomotorik), bahan ajar, metodologi (bervariasi sesuai kemampuan guru), sarana sekolah, dukungan administrasi dan sarana prasarana dan sumber daya lainnya serta penciptaan suasana yang kondusif. Mutu pembelajaran ditentukan dengan metode, input, suasana, dan kemampuan melaksanakan manajemen proses pembelaran itu sendiri.

Pembelajaran yang bermutu adalah pembelajaran yang efektif yang pada intinya adalah menyangkut kemampuan guru dalam proses pembelajaran di kelas. Proses pembelajaran yang dilakukan oleh guru akan sangat menentukan mutu hasil pembelajaran yang akan diperoleh siswa.

Berdasarkan uraian diatas dapat disimpulkan bahwa mutu pembelajaran adalah Pembelajaran yang dilakukan oleh guru akan sangat menentukan mutu pembelajaran yang akan diperoleh siswa. Indikator mutu pembelajaran dalam penelitian ini, yaitu kesesuaian, 
pembelajaran yang bermutu juga harus mempunyai daya tarik yang kuat, efektivitas, efisiensi, dan produktivitas

\section{b. Indikator Mutu Belajar dan Pembelajaran.}

Prestasi sekolah yang dihasilkan dari proses atau prilaku sekolah. Menurut Arcaro $^{46}$ Kinerja sekolah dapat diukur dari kualitasnya, efektivitasnya, produktivitasnya, efisiensinya, inovasinya, kualitas kehidupan kerjanya, dapat dijelaskan bahwa output sekolah dikatakan berkualitas atau bermutu tinggi jika prestasi sekolah, khususnya prestasi belajar siswa, menunjukan pencapaian yang tinggi dalam:

1) Prestasi akademik, berupa nilai ulangan umum, ujian akhir nasional (UAN), karya ilmiah, lomba akademik

2) Prestasi non-akademik, seperti IMTAQ, kejujuran, kesopanan, olahraga, kesenian, keterampilan kegiatan ektrakurikuler lainya.

\section{METODE PENELITIAN}

\section{Pendekatan dan Jenis Penelitian}

Jenis penelitian ini adalah penelitian kualitatif. Penelitian kualitatif adalah penelitian yang bermaksud untuk memahami fenomena tentang apa yang dialami oleh subjek penelitian misalnya perilaku, persepsi, motivasi, tindakan, dan lain-lain. dengan alasan (1) data penelitian bersifat alamiah, (2) penelitian ini mementingkan proses, dan (3) data merupakan data deskriptif yang berupa kata-kata, frase, kalimat atau teks khusus yang alamiah dan dengan memanfaatkan berbagai metode alamiah.

Adapun jenis penelitian yang digunakan adalah study kasus (case study) yaitu penelitian yang dilakukan secara intensif, terinci dan mendalam terhadap suatu organisasi, lembaga atau gejala

${ }^{46} \mathrm{~J}$. Arcaro, Pendidikan Berbasis Mutu .(Yogyakarta: Pustaka Pelajar. 2006), 98 tertentu $^{47}$. Oleh karena itu, hasil penelitian ini diharapkan dapat memberikan suatu gambaran yang utuh dan terorganisasi dengan baik tentang komponen-komponen tertentu sehingga dapat memberikan kevalidan hasil penelitian.

\section{Instrumen Penelitian}

Instrumen penelitian ini adalah peneliti sendiri, karena peneliatian ini merupakan penelitian kualitatif, dalam penelitian kualitatif ini peneliti bertindak sebagai Key Instrument penelitian. Sebagaimana John W. Creswell menyatakan bahwa "peran peneliti dianggap sebagai instrumen primer, maka bagian awal penelitian diperlukan adanya identifikasi terhadap nilai-nilai, asumsi-asumsi, dan biasbias personal (peneliti) ${ }^{\prime 48}$.

Dalam penelitian ini peneliti berperan sebagai pengamat partisipan pasif yaitu peneliti hanya mengamati obyek penelitian (fenomena atau tingkah laku informan dan responden) untuk mengetahui bagaimana penerapan kurikulum terintegrasi dalam mengembangkan mutu belajar siswa di SMA Darul 'Ulum 1 Unggulan BPPT Jombang.

\section{Langkah-langkah Penelitian}

Dalam penelitian ini peneliti menggunakan tahap penelitian sesuai dengan model tahapan Moleong, yaitu: tahap pra lapangan, tahap pekerjaan lapangan, tahap analisis data, tahan penulisan laporan

\section{Sumber dan Data Penelitian}

Dalam penelitian ini sumber dan data penelitian yang dimaksud adalah dari mana data penelitian di peroleh. Maka sumber data dalam penelitian ini adalah informan, informannya adalah kepala sekolah, waka kurikulum, guru dan siswa SMA Darul 'Ulum 1 Unggulan BPPT Jombang serta pihak lain yang terkait.

\footnotetext{
${ }^{47}$ Suharsimi Arikunto, Prosedur Penelitian Suatu Pendekatan Praktek, (Jakarta: Rineka Cipta, 2006), 142. 48 John Creswell, Research Design. Terjemahan Oleh Achmad Fawaid. (Yogyakarta: Pustaka Belajar, 2010), 294
} 
Adapun data penelitian ini adalah perencanaan, pelaksanaan, model dan evaluasi penerapan kurikulum terintegrasi serta mutu atau kualitas belajar siswa dalam aspek kognitif, afektif dan psikomotor di SMA Darul 'Ulum 1 Unggulan BPPT Jombang.

\section{Teknik Pengumpulan Data}

Teknik pengumpulan data merupakan langkah yang paling strategis dalam penelitian, karena tujuan utama dari penelitian adalah mendapatkan data. ${ }^{49}$ Dalam penelitian ini, peneliti mengumpulkan data dengan teknik: (1) wawancara; (2) observasi atau pengamatan; dan (3) studi dokumentasi. Ketiga teknik pengumpulan data ini merupakan teknik dasar yang digunakan dalam penelitian kualitataif.

\section{Analisis Data}

Teknik analisis data pada penelitian ini menggunakan teknik analisis deskriptif. Menurut $^{50}$ teknik analisis deskriptif adalah prosedur atau cara memecahkan masalah penelitian dengan memaparkan keadaan objek yang diselidiki (seseorang, lembaga, masyarakat, pabrik, dan lain-lain) sebagaimana adanya berdasarkan fakta-fakta yang aktual.

Menurut Moleong ${ }^{51}$ deskriptif yaitu data yang dikumpulkan adalah berupa kata-kata, gambar-gambar dan bukan angka-angka. Dengan demikian, laporan penelitian akan berisi kutipan-kutipan data untuk memberi gambaran penyajian laporan tersebut. Data tersebut mungkin berasal dari naskah wawancara, catatan lapangan, foto, video tape, dokumen pribadi, catatan atau memo, dan dokumen resmi lainnya.

Analisis data yang digunakan peneliti dalam penelitian ini meliputi: Reduksi Data, Penyajian Data (data display) dan Menarik Kesimpulan

\footnotetext{
${ }^{49}$ Sugiyono, Memahami Penelitian Kualitatif, (Bandung: Alfabeta, 2008), 224.

${ }^{50}$ Hadari Nawawi, Organisasi Sekolah dan Pengelolaan Kelas, (Jakarta: Haji Mas Agung, 1989), 6.

${ }^{51}$ Lexy J. Moleong. Metodologi Penelitian Kualitatif, (Bandung: Remaja Rosdakarya, 2005), 11.
}

\section{Pengecekan Keabsahan data}

Untuk pengecekan keabsahan data peneliti menggunakan teknik sebagai berikut: Perpanjangan keikutsertaan, ketekunan pengamatan dan triangulasi

D. HASIL DAN PEMBAHASAN

1. Penerapan Kurikulum Terintegrasi di SMA Darul Ulum BPPT Jombang

a. Model Kurikulum Terintegrasi di SMA Darul 'Ulum 1 BPPT Jombang

Model kurikulum

terintegrasi yang diterapkan di SMA Darul 'Ulum 1 BPPT Jombang yang ditemukan peneliti yaitu: Pertama, Sistem pendidikan terpadu yaitu perpaduan antara kurikulum nasional dan kurikulum pondok, maksudnya memasukkan kurikulum pondok kedalam kurikulum nasional.

Hal ini sejalan dengan Forgarty dalam Syaifuddin Sabda mendefinisikan kurikulum terpadu (integrated curriculum) sebagai suatu model kurikulum yang dapat mengintegrasikan skills, themes, concepts, and topics secara inter dan antar disiplin atau penggabungan keduanya. $^{52}$

Kedua, perpaduan antara materi PAI Diknas dengan materi pondok. Perpaduan ini maksudnya memasukan materi-materi pondok yang ada kaitannya dengan materi PAI. Perpaduan ini termasuk model kurikulum terintegrasi interdisipliner yaitu perpaduan antara mata pelajaran yang serumpun.

Hal ini sesuai teori Robin Fogarty dalam Trianto $^{53}$ model

52 Syaifuddin Sabda, Pengembangan Kurikulum (Tinjauan Teoritis), (Yogyakarta: Aswaja Presindo,2006). 28-29

53 Trianto. Model Pembelajaran Terpadu dalam Teori dan Praktek. (Jakarta: Prestasi Pustaka Publisher, 2007), 40 
kurikulum terintegrasi dikelompokkan menjadi 3 (tiga) klasifikasi pengintegrasian kurikulum, sebagai berikut:

a. Pengintegrasian di dalam Satu Disiplin Ilmu

Model ini merupakan integrasi yang mentautkan dua atau lebih bidang ilmu yang serumpun. Misalnya di bidang Ilmu Alam, mentautkan antara dua tema dalam fisika dan biologi yang memiliki relevansi, atau antara tema dalam kimia dan fisika. Contoh: tema metabolisme dapat ditinjau dari biologi maupun kimia. Begitupun dengan tematema yang relevan pada Ilmu Sosial seperti antara sosiologi dan geografi. Jadi sifat perpaduan dalam model ini hanya dalam satu rumpun bidang ilmu saja (inter-disipliner).

b. Pengintegrasian

Beberapa

Disiplin Ilmu

Model ini merupakan integrasi yang mentautkan antar disiplin ilmu yang berbeda. Misalnya antara tema yang ada dalam bidang ilmu sosial dengan bidang ilmu alam. Sebagai contoh, tema energi merupakan tema yang dapat dikaji dari bidang ilmu yang berbeda baik dalam bidang ilmu sosial (tentang kebutuhan energi dalam masyarakat), dan bidang ilmu alam (tentang bentuk-bentuk energi dan teknologinya).

c. Pengintegrasian di dalam Satu dan Beberapa Disiplin Ilmu

Model ini merupakan integrasi yang paling kompleks karena mentautkan antar disiplin ilmu yang serumpun sekaligus bidang ilmu yang berbeda. Misalnya, antara tema yang ada dalam bidang ilmu sosial, bidang ilmu alam, teknologi maupun ilmu agama. Sebagai contoh, tema rokok merupakan tema yang dapat dikaji dari berbagai bidang ilmu yang berbeda.

Ketiga, Perpaduan antara kegiatan sekolah dengan kegiatan pondok. kegiatan-kegiatan sekolah dipadukan atau dijadikan satu dengan kegiatan asrama sehingga tidak ada yang namanya kegiatan pondok ataupun kegiatan asrama.

Hal ini tidak cocok dengan teory Fogarty mengemukakan 10 model yaitu : 1). Fragmented, 2).Connected, 3). Nested, 4). Sequenced, 5). Shared, 6). Webbed 7). Threaded, 8). Integrated, 9). Immersed dan 10). Networked. Model ini tidak termasuk dalam kategori sepuluh model diatas. ${ }^{54}$

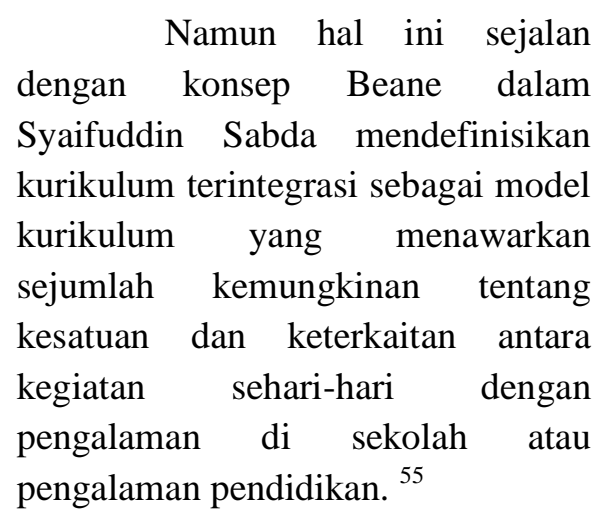

\footnotetext{
${ }^{54}$ Trianto. Model Pembelajaran Terpadu dalam Teori dan Praktek. (Jakarta: Prestasi Pustaka Publisher, 2007), 122.

55 Syaifuddin Sabda, Pengembangan Kurikulum (Tinjauan Teoritis), (Yogyakarta: Aswaja Presindo,2006). 28-29.
} 


\section{b. Perencanaan Penerapan Kurikulum Terintegrasi di SMA Darul 'Ulum 1 BPPT Jombang}

Perencanaan bertujuan untuk mencapai seperangkat operasi yang konsisten dan terkoordinasi guna memperoleh hasil-hasil yang diinginkan. Secara mendasar, perencanaan adalah suatu proses intelektual yang melibatkan pembuatan keputusan. Proses ini menuntut prediposisi mental untuk berpikir sebelum bertindak, berbuat berdasarkan kenyataan bukan perkiraan, dan berbuat sesuatu secara teratur. ${ }^{56} \mathrm{Hal}$ ini, menekankan bahwa perencanaan dalam pengembangan kurikulum terintegrasi merupakan suatu keharusan yang tidak terelakkan. Begitu juga harus mampu mengintegrasi perencanaan dengan tujuan pendidikan di masing-masing skala, apakah skala nasional, institusional, kurikuler dan intruksional. Tentunya hal ini perlu dilakukan penyusunan yang melibatkan beberapa pihak.

Penyusunan kurikulum, SMA Darul Ulum 1 Unggulan BPPT Jombang melibatkan berbagai pihak diantaranya kepala sekolah, guru, yayasan, komite, tim BPPT kita libatkan untuk perumusan kurikulum dan masyarakat. Setelah kurikulum disusun maka tugas masing-masing guru mapel untuk untuk membuat perencanaa KBM, yaitu membuat silabus, RPP, menyusun strategi pembelajaran dan sebagainya yang nantinya diperlukan ketika KBM berlangsung.
56 Oemar Hamalik, Manajemen Pengembangan Kurikulum. (Bandung: UPI dan Remaja Rosdakarya, 2008.), 134.
Hal ini ada kemiripan dan kesesuaian dengan teori yang dikemukakan C.C. Freeman dan H.J. Sokoloff mengemukakan bahwa halhal yang penting diperhatikan oleh guru ialah: mengientifikasi suatu topic, mengembangkan interpretasi visual (membuat peta konsep atau jaringan terbuka) bagi ide-ide dan fakta-fakta yang berhubungan dengan topik dan tema, dan mengidentifikasi materi pembelajaran serta merancang aktivitas pembelajaran. ${ }^{57}$ Namun, hal diatas tidak sejalan dengan pendapat Burhan Nurgiyantoro, untuk menyusun perencanan kurikulum terintegrasi, maka harus memperhatikan bentuknya sebagai berikut: Pertama, unit merupakan satu kesatuan dari seluruh bahan pelajaran. Faktor yang menyatukan adalah masalah-masalah yang akan diselidiki dan dipecahkan oleh peserta didik. Kedua, unit didasarkan pada kebutuhan peserta didik baik yang bersifat pribadi maupun sosial, baik yang menyangkut jasmani dan rohani. Dengan sistem unit ini, akan meningkatkan perkembangan sosial peserta didik dengan banyak memberikankesempatanbekerjasama dalam kelompok.

Ketiga, dalam unit peserta didik dihadapkan pada berbagai situasi yang mengandung permasalahan yang berhubungan dengan kehidupan sehari-hari dan dikaitkan dengan pelajaran di sekolah sesuai dengan tingkat kemampuan peserta didik. Keempat, unit mempergunakan dorongan-dorongan sewajarnya pada diri peserta didik dengan melandaskan diri pada teori-teori belajar. Kelima, pelaksanaan unit sering memerlukan

57 Syaifuddin Sabda, Pengembangan Kurikulum (Tinjauan Teoritis), (Yogyakarta: Aswaja Presindo,2006). 102. 
waktu yang relatif lebih lama daripada pelajaran biasa di kelas. ${ }^{58}$

c. Pelaksanaan

Kurikulum

Terintegrasi di SMA Darul Ulum Jombang

1) Materi dan Alokasi Waktu

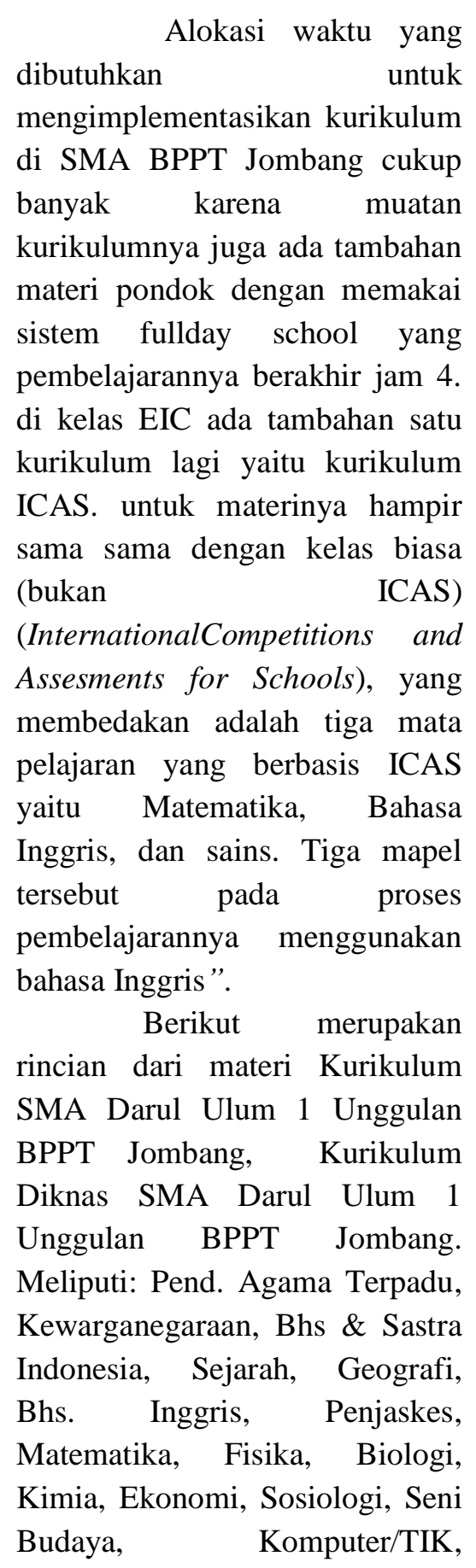

Ketramp/Bahasa Asing/B.Arab, Muatan Lokal/B Daerah dan Pengembangan Diri/BP

Adapun Kurikulum Pondok di SMA Darul Ulum 1 Unggulan BPPT Jombang meliputi: Ilmu Tajwid, Qur'an - Hadits , Fiqih, Aqidah - Akhlaq, S K I

- Kedarululuman, Nahwu Shorof - Baca Kitab, Bimbingan Membaca Kitab

Pengaturan mata pelajaran dengan waktu ini sangat penting dalam sebuah kurikulum hal ini sebagaimana Sabda $^{59}$, Penentuan kerangka waktu umum sangat penting dalam sebuah kurikulum terpadu. Penetuan kerangka waktu ini berkaitan dengan upaya mengorganisir kegiatan dimana materi-materi pada masing- masing mata pelajaran terkait disajikan dalam waktu yang telah ditentukan.

\section{2) Kegiatan Belajar Mengajar SMA} Darul 'Ulum 1 BPPT Jombang

Pelaksanaan dalam

pembelajaran yang dilaksanakan oleh masing-masing guru bidang studi sama dengan sekolah lainnya. Ketika pelaksanaan KBM maka mengacu pada perencanaan yang sudah dibuat yang ada di RPP. Antara lain apresiasi, motivasi, kegiatan inti, metoden, media, semuanya sama menyesuaikan dengan mata pelajaran. Pada kegiatan inti PAI maka hal yang pertama dilakukan adalah memaknai kitab, meskipun hanya sedikit baru nanti kita jelaskan sesuai urutan materi yang ada di PAI. Ini wujud daripada integrasi kurikulum dari pemerintah

\footnotetext{
58 Burhan Nurgiyantoro, Penilaian Pembelajaran Bahasa Berbasis Kompetensi. (Yogyakarta: Badan Percetakan Fakultas Ekonomi Universitas Negeri Yogyakarta. 2013), 119.
}

59 Syaifuddin Sabda, Pengembangan Kurikulum (Tinjauan Teoritis), (Yogyakarta: Aswaja Presindo,2006). 69. 
dengan kurikulum pondok, sedangkan materi umum yang terkait dengan agama, dijelaskan sedikit oleh masingmasing guru. Pada peerapannya murid adalah sebagai pusat daripada pembelajaran.

Hal ini sejalan dengan Oemar Hamalik bahwa dalam pendekatan pelaksanaan kurikulum terintegrasi, peserta didik adalah pembuat keputusan dan para pemecah masalah. Proses dipandang sebagai sentral untuk menjelaskan tingkah laku. Peserta didik itu berbeda satu sama lain, sedangkan masalah merupakan kunci dimana proses dimulai, karena itu pula cara penyelesaian masalah pun berbeda satu sama lain, tidak ada dua cara yang sama. Para peserta didik bukan saja dikembangkan sebagai suatu kepribadian yang bulat, akan tetapi juga dipersiapkan sebagai pribadi yang mampu berperan di masyarakat. Selain dari itu, pendekatan ini memungkinkan kerjasama antara sekolah dan masyarakat. ${ }^{60}$

3) Kegiatan SMA Darul 'Ulum 1 BPPT Jombang diluar Kegiatan Belajar Mengajar

Kegiatan SMA Darul Ulum

1 Unggulan BPP Teknologi memiliki ciri khas keterpaduan antara pendidikan formal umum dengan pendidikan agama di Pondok Pesantren. Ciri khas tersebut meliputi hal- hal sebagai berikut : Wawasan

Keunggulan Imtaq meliputi: pendisiplinan sholat lima waktu dan harus berjama'ah, rutinitas membaca al qur'an baik di asrama maupun di sekolah pada awal kbm serta pada waktu ba'da maghrib dan subuh, penanaman sikap santri yang

${ }^{60}$ Oemar Hamalik, Manajemen Pengembangan Kurikulum. (Bandung: UPI dan Remaja Rosdakarya, 2008.), 60-62. menjadikan perilaku nabi muhammad saw sebagai suri tauladan, melalui penempelan hadisthadist nabi pada tempat-tempat tertentu mengkaji dan memahami hukum-hukum Islam dan kitab kuning sebagai karya ilmiah para ulama' besar Islam. Wawasan Keunggulan Iptek meliputi: Wawasan keunggulan bidang Iptek terwujud dalam kegiatan Penambahan alokasi jam belajar MIPA, Kegiatan Karya ilmiah (KIR) , Pengikutsertaan pada lomba-lomba karya ilmiah baik berskala regional maupun nasional, dan Pengadaan dan pengembangan sarana laboratorium IPA dan Komputer. Wawasan Keunggulan Berbahasa Inggris meliputi: English morning, English Area dan Excellent English Club (EEC). Wawasan Keunggulan Budi Pekerti (Akhlakul Karimah)

Hal diatas sesuai dengan teori Beane dalam Syaifuddin Sabda mendefinisikannya sebagai model kurikulum yang menawarkan sejumlah kemungkinan tentang kesatuan dan keterkaitan antara kegiatan sehari-hari dengan pengalaman di sekolah atau pengalaman pendidikan. ${ }^{61}$

d. Evaluasi Kurikulum Terintegrasi di SMA Darul Ulum BPPT Jombang

Evaluasi di SMA Darul Ulum 1 Unggulan BPPT Jombang dilakukan dalam rangka mengetahui sejauh mana ketercapaian tujuan pembelajaran, hal ini sejalan dengan Zaini yang menyatakan evaluasi adalah suatu tindakan atau suatu proses untuk menentukan nilai dari sesuatu. Evaluasi dalam pendidikan dapat

61 Syaifuddin Sabda, Pengembangan Kurikulum (Tinjauan Teoritis), (Yogyakarta: Aswaja Presindo,2006). 28-29 
diartikan sebagai suatu proses dalam usaha untuk mengumpulkan informasi yang dapat digunakan sebagai bahan pertimbangan untuk membuat keputusan akan perlu tidaknya memperbaiki sistem pembelajaran sesuai dengan tujuan yang akan ditetapkan. Tyler seperti yang dikutip Sukmadinata menyatakan bahwa evaluasi adalah proses untuk mengetahui apakah tujuan pendidikan sudah tercapai atau terealisasikan. ${ }^{62}$

Evaluasi di SMA Darul 'Ulum

1 ditandai dengan adanya pelaksanaan ulangan harian, ujian tengah semester, ujian akhir semester, ujian praktek, penilaian sikap, penilain diri, dan penilaian keterampilan. Artinya evaluasi yang diterapkan yaitu evaluasi yang bersifat sumatif juga formatif.

Hal ini sesuai dengan pendapat rusman tentang evaluasi sumatif dan formatif yaitu Evaluasi formatif adalah evaluasi atau penilaian yang dilakukan setelah satu pokok bahasan selesai dipelajari oleh peserta didik. Evaluasi sumatif adalah tes yang diselenggarakan oleh guru setelah menempuh satu jangka waktu tertentu. Dalam pelaksanaan tes sumatif ini sering disebut dengan ulanngan atau ujian semester, atau ulangan umum nasional dan biasanya diselenggarakan secara serempak untuk seluruh sekolah. ${ }^{63}$

Jenis evaluasi yang diterapkan juga memakai jenis evaluasi tes dan non tes. Sesuai pendapat arikunto yaitu Dalam evaluasi kurikulum

62 Muhamad Zaini, Pengembangan Kurikulum: Konsep, Implementasi, Evaluasi dan Inovasi. (Yogyakarta: Teras. 2009), 142-143.

${ }^{63}$ Rusman, Manajemen Kurikulum. (Jakarta: RajaGrafindo Persada, 2009),101 terintegrasi, penilaian pencapaian kompetensi dasar peserta didik dilakukan berdasarkan indikator. Penilaian dilakukan dengan menggunakan tes dan non tes dalam bentuk tertulis maupun lisan, pengamatan kinerja, pengukuran sikap, penilaian hasil karya berupa tugas, proyek dan/atau produk, penggunaan portofolio dan penilaian diri. Adapun penilaian atau evaluasi kurikulum terintegrasi, sebagaimana bagan berikut. ${ }^{64}$

\section{Mutu belajar di SMA Darul Ulum BPPT Jombang}

a. Mutu belajar siswa aspek kognitif

Mutu belajar pada aspek kognitif dapat dilihat dari prestasiprestasi yang diraih siswa bidang akademis semakin banyak dan juga hasil belajar siswa dari nilai ulangan, UTS, UAS, dan UN yang semakin meningkat.

Hal ini sesuai dengan teori, ${ }^{65}$ Muh. Uzer Usman dalam bukunya Menjadi guru merdeka mengklasifikasikan tujuan kognitif atas enam bagian, yaitu sebagai berikut:

Ingatan / recall. Mengacu pada kemampuan mengenal atau mengingat materi yang sudah dipelajari dari yang sederhana sampai pada teori-teori yang sukar. Yang penting adalah kemampuan mengingat keterangan dengan benar. Pemahaman. Mengacu kepada kemampuan memahami makna materi.aspek ini satu tingkat di atas pengetahuan dan merupakan tingkat kemampuan berpikir yang rendah.

64 Trianto. Model Pembelajaran Terpadu dalam Teori dan Praktek. (Jakarta: Prestasi Pustaka Publisher, 2007), 94.

${ }^{65}$ Moh.Uzer Usman, Menjadi Guru Profesional. (Bandung : PT. Remaja Rosdakarya, 2002), 12. 
Penerapan. Mengacu pada

kemampuan menggunakan atau menerapkan materi yang sudah dipelajari pada situasi yang baru dan menyangkut penggunaan aturan, prinsip. Penerapan merupakan tingkat kemampuan berpikir yang lebih tinggi daripada pemahaman. Analisis. Mengacu kepada kemampuan menguraikan materi ke dalam komponen-komponen atau faktro penyebabnya, dan mampu memahami hubungan di antara bagian yang satu dengan yang lainnya sehingga struktur dan aturannya dapat lebih dimengerti. Analisis merupakan tingkat kemampuan berpikir yang lebih tinggi daripada aspek pemahaman maupun penerapan. Sintesis. Mengacu pada kemampuan memadukan konsep atau komponenkomponen sehingga membentuk suatu pola srtuktur atau bentuk baru. Aspek ini memerlukan tingkah laku yang kreatif. Sintesis merupakan kemampuan tingkat berpikir yang lebih tinggi daripada kemampuan sebelumnya. Evaluasi. Mengacu pada kemampuan memberikan pertimbangan terhadap nilai-nilai materi untuk tujuan tertentu. Evaluasi merupakan tingkat kemampuan berpikir yang lebih tinggi.

b. Mutu belajar siswa aspek apektif

Dalam ranah apektif mutu belajar siswa di SMA Darul 'Ulum 1 dapat dilihat dari perubahan sikap, moral, minat dan rasa menghargai siswa pada saat di kelas ataupun diluar kelas baik dengan guru maupun dengan siswa yang lainnya.

Hal ini sesuai dengan pendapat sudjana yaitu aspek apektif Ini lebih banyak menitikberatkan pada bidang sikap dan tingkah laku. Aspek ini berkaitan dengan sikap mental, perasaan dan kesadaran siswa. Prestasi belajar ini diperoleh melalui proses internalisasi, yaitu suatu proses kearah pertumbuhan batiniah atau rohaniah siswa ${ }^{66}$

Hal ini juga diperkuat dengan pendapat Ana Sudjono tentang ciri-ciri hasil belajar apektif tampak pada siswa dalam berbagai tingkah laku seperti: perhatian terhadap mata pelajaran, kedisiplinan dalam mengikuti proses belajar, motivasinya dalam belajar, penghargaan atau rasa hormatterhadap guru, dan sebagainya ${ }^{67}$

c. Mutu belajar siswa aspek psikomotorik

Mutu belajar siswa pada aspek psikomotorik di SMA Darul 'Ulum 1 BPPT Jombang ini dapat dilihat dari kegiatan-kegiatan siswa, hasil keterampilan siswa dan kompetensi yang diraih baik ditingkat kabupaten, provinsi maupun nasional.

Hal diatas sejalan dengan pendapat Depdiknas yaitu Ranah psikomotor adalah ranah yang berkaitan dengan keterampilan (Skill) atau kemampuan bertindak setelah seseorang menerima pengalaman belajar tertentu. Mata ajar yang termasuk kelompok mata ajar psikomotor adalah mata ajar yang lebih berorientasi pada gerakan dan menekankan pada reaksi-reaksi fisik.

Hal ini sejalan dengan pendapat Arcaro ${ }^{68}$, Kinerja sekolah dapat diukur dari kualitasnya, efektivitasnya, produktivitasnya, efisiensinya, inovasinya, kualitas kehidupan kerjanya, dapat dijelaskan bahwa output sekolah dikatakan berkualitas atau bermutu tinggi jika

\footnotetext{
66 Anas Sudijono. Pengantar Evaluasi Pendidikan. (Jakarta: Paja Grafindo Persada. 2005), 76

67 Anas Sudijono. Pengantar Evaluasi Pendidikan. (Jakarta: Paja Grafindo Persada. 2005), 54.

68 J. Arcaro, Pendidikan Berbasis Mutu .(Yogyakarta:
} Pustaka Pelajar. 2006), 98 
prestasi sekolah, khususnya prestasi belajar siswa, menunjukan pencapaian yang tinggi dalam: Prestasi akademik, berupa nilai ulangan umum, ujian akhir nasional (UAN), karya ilmiah, lomba akademik dan Prestasi nonakademik, seperti IMTAQ, kejujuran, kesopanan, olahraga, kesenian, keterampilan kejuruan, dan kegiatankegiatan ektrakurikuler lainya..

\section{E. KESIMPULAN}

Penerapan kurikulum terintegrasi di SMA Darul 'Ulum 1 BPPT Jombang yaitu: a) Model kurikulum terintegrasinya yaitu sistem pendidikan terpadu antara kurikulum nasional dan kurikulum pondok, materi PAI terpadu yaitu perpaduan antara PAI diknas dengan materi pondok, keterpaduan antara kegiatan sekolah dan pondok. b) Perencanaan kurikulum melibatkan kepala sekolah, guru, yayasan, komite, tim BPPT. Setelah kurikulum disusun maka tugas guru mapel untuk untuk membuat perencanaa KBM, yaitu membuat silabus, RPP, menyusun strategi pembelajaran dan sebagainya.c)Pelaksanaan kurikulumnya mengacu pada perencanaan yang sudah dibuat yang ada di RPP. Memiliki ciri khas keterpaduan antara pendidikan formal umum dengan pendidikan agama di Pondok Pesantren. d) Evaluasi yang digunakan adalah evaluasi sumatif dan formatif dan jenis evaluasinya yaitu evaluasi tes non tes untuk. 2. Mutu belajar aspek kognitif dilihat dari dilihat dari prestasi-prestasi yang diraih siswa bidang akademis semakin banyak dan juga hasil belajar siswa dari nilai ulangan, UTS, UAS, dan UN yang semakin meningkat, aspek apektif dibuktikan dengan perubahan sikap, moral, minat dan rasa menghargai siswa pada saat di kelas ataupun diluar kelas baik dengan guru maupun dengan siswa yang lainnya aspek psikomotorik dilihat dari kegiatan-kegiatan, hasil keterampilan dan kompetensi yang diraih baik ditingkat kabupaten, provinsi maupun nasional. .

\section{F. REFERENSI}

Ahmad Saebani, Beni. 2009. Ilmu pendidikan Islam. Bandung: Pustaka Setia.

Ali, Muhammad. 2009. Pengembangan Kurikulum di Sekolah. Bandung:

Sinar Baru Algensindo.

Dahlan, Pius. 2001. Kamus Ilmiah Populer. Surabaya: Arkola.
Hamalik, Oemar. Manajemen
Pengembangan Kurikulum.
Bandung: UPI dan Remaja
Rosdakarya, 2008.

Langgulung, Hasan. 1979. Filsafat

Pendidikan Islam. Jakarta: Bulan

Bintang.

Majid, Abdul. 2009. Perencanaan

Pembelajaran, Mengembangkan

Standar Kompetensi Guru. Bandung:

Remaja Rosdakarya.

Zaini, Muhamad. 2009. Pengembangan

Kurikulum: Konsep, Implementasi,

Evaluasi dan Inovasi. Yogyakarta:

Teras.

Nasution, S. 1991. Pengembangan Kurikulum

Pendidikan. Bandung: Citra Adirya Bakti.

1995. Asas-Asas Kurikulum. Jakarta: Bumi Aksara.

Nata, Abuddin. 2005. Filsafat Pendidikan Islam. Jakarta: Gaya Media Pratama.

Notoatmodjo, $\quad$ Soekidjo. 2009.

Pengembangan Sumber Daya

Manusia. Jakarta: Rineka Cipta.

Fogarty, Robin. How to Integrate the Curricula. USA: CorwinPress

Rusman, 2009. Manajemen Kurikulum. Jakarta: RajaGrafindo Persada

2012. Manajemen Kurikulum. Jakarta: Rajawali Press.

S. Arcaro, Jarome , 2006. Pendidikan

Berbasisis Mutu Prinsip-Prinsip

Perumusan dan Tata Langkah

Penerapan. Yogyakarta:Pustaka Pelajar.

Sa'dun. Akbar, dan Hadi Sriwiyana. 2010. Pengembangan kurikulum dan 
Nidhomul Haq, Vol 3 No 2 Tahun 2018

Pembelajaran Ilmu Pengetahuan

Sosial (IPS). Yogyakarta: Cipta

Media.

Sabda, Syaifuddin. 2006. Model Kurikulum Terpadu IPTEK dan IMTAQ (Desain, Pengembangan \& Implementasi). Ciputat: Ciputat Press Group

Sanjaya, Wina. 2009. Kurikulum dan Pembelajaran: Teori dan Praktik Pengembangan Kurikulum Tingkat Satuan Pendidikan (KTSP), Jakarta: Kencana.

Tim Penyusun. 2005. UU RI no 20 Tahun 2003 Tentang Sisdiknas. Surabaya: Media Centre.

Trianto, 2007. Model Pembelajaran Terpadu: Teori dan Praktek, Jakarta: Prestasi Pustaka

Trianto. 2007. Model Pembelajaran Terpadu dalam Teori dan Praktek. Jakarta: Prestasi Pustaka Publisher.

Umar, Bukhori. 2011. Ilmu Pendidikan Islam. Jakarta: AMZAH,

Zainuddin, M. 2013. Paradigma Pendidikan Terpadu: Menyiapkan Generasi Ulul Albab. Malang: UIN Maliki Press. 